\title{
Utilization of molecular markers for the conservation of blood cockles, Anadara granosa (Arcidae)
}

\author{
S.Y. Chee ${ }^{1}$, M.N.S. Azizah ${ }^{1}$ and M.N. Devakie ${ }^{2}$ \\ ${ }^{1}$ School of Biological Sciences, Universiti Sains Malaysia, Penang, Malaysia \\ ${ }^{2}$ Fisheries Research Institute, Batu Maung, Penang, Malaysia \\ Corresponding author: S.Y. Chee \\ E-mail: suyinchee@gmail.com
}

Genet. Mol. Res. 10 (2): 1245-1261 (2011)

Received October 14, 2010

Accepted January 17, 2011

Published June 28, 2011

DOI 10.4238/vol10-2gmr1103

\begin{abstract}
We examined genetic variation in blood cockles in an effort to obtain information useful for the sustainability, management, and the stability of this species as a major commodity in the fisheries sector. Ten populations of cockles were sampled from the north to the south of the west coast of peninsular Malaysia. The cockles were collected in collaboration with the Fisheries Research Institute, Penang. The population genetic analysis of the cockles were studied via RAPD-PCR and mtDNA sequencing. Three hundred individuals were analyzed with RAPD-PCR experiments. High gene diversity over all loci was observed (Shannon index $=0.549 \pm 0.056$ and Nei's gene diversity $=0.4852 \pm 0.0430$ among 35 loci). The second method, mtDNA sequencing, was employed to complement the information obtained from RAPD-PCR. The gene selected for mtDNA sequencing was cytochrome c oxidase I (COI). One hundred and fifty individuals were sequenced, yielding a partial gene of $585 \mathrm{bp}$. Statistical analysis showed homogeneity in general but did reveal some degree of variability between the populations in Johor and the rest of the populations. The Mantel test showed a positive but nonsignificant correlation between geographic and genetic distances $(r=0.2710, P=0.622)$, as in the RAPD
\end{abstract}


analysis. We propose that the homogeneity between distant populations is caused by two factors: 1) the translocation of the spats; 2) larvae are carried by current movement from the north of the peninsula to the south. The different genetic composition found in Johor could be due to pollution, mutagenic substances or physical factors such as the depth of the water column. This population genetic study is the first for this species in peninsular Malaysia. The data from this study have important implications for fishery management, conservation of blood cockles and translocation policies for aquaculture and stock enhancement programs.

Key words: RAPD; mtDNA; Anadara granosa; Population study

\section{INTRODUCTION}

The blood cockle, Anadara granosa, is an arcid bivalve mollusk. They are benthic organisms with a sessile adult stage and a pelagic larval stage. They are found widespread in the Indo-West Pacific, from East Africa, including Madagascar and the Red Sea, to eastern Polynesia, from northern to southern Japan and Hawaii, and from southern to northern Australia and New Caledonia (FAO, 2006). Their distribution depends heavily on the salinity of the water, and they are found most commonly under brackish sand and fine, soft, mud bottoms. Malaysia's output of blood cockles was ranked 5th in Asia and the Pacific with 78,712 tonnes in 2002, contributing to a total export of US\$525,546,000 worth of fishery products (Pawiro, 2004). At present, 4000 to 5000 hectares of the west coast of Peninsular Malaysia are used for cockle culture (FAO, 2006).

While natural breeding and recruitment of cockles predominantly support the industry, translocation of spats (recently settled young cockles) between cockle leases, often separated by a distance of several hundred kilometers, is very frequent. The larval dispersal patterns of most bivalves are poorly understood. Similarly, the origins of naturally recruited cockle spats in Malaysia are unknown, as is the impact of translocations on natural population structure and genetic variability. The mixing of hatchery-reared cockles and pure wild stocks found in open water bodies may result in less well-adapted cockles compared to the native stock. Thus, genetic baseline data for monitoring potential changes in the genetic makeup and adaptive values, as a result of interaction between wild and cultured populations of this economically important species, are needed for a systematic management of the species.

Random amplified polymorphic DNA (RAPD) analysis is a simple, efficient and costeffective molecular approach for population studies. However, it has several disadvantages, which include its dominant characteristic problems in reproducibility and sensitivity to changes in reaction conditions. Despite these potential limitations, this method has been extensively used to detect the genetic diversity in shellfish such as the greenshell mussel, Perna canaliculus (Star et al., 2003) and the scallop, Chlamys farreri (Liu et al., 2006). Using careful and uniform procedures, RAPD data have been shown to be reliable and informative in those investigations.

mtDNA is recognized as a very important tool in the study of population genetics and historical biogeography (Riddle and Hafner, 2007). Sequencing of the fast-evolving COI gene is particularly useful when analyzing taxonomic distinctiveness and variability of populations to set priorities for conservation programs. This has been documented in many bivalve species 
such as the freshwater mussel Anodonta woodiana (Soroka, 2008) and the amblemine freshwater mussel (Walker et al., 2007).

For this study, RAPD and mtDNA COI gene markers were applied to assess intraspecific nuclear and mitochondrial genetic variation and relatedness among populations of $A$. granosa as an approach to its management and conservation.

\section{MATERIAL AND METHODS}

\section{Sample collection}

A total of 300 adult cockles were collected from 10 populations ( 30 per sample) along the west coast of Peninsular Malaysia in the period of 2007-2008. These areas are located off the northern States of Kedah (Tanjung Dawai) and Penang (Kuala Juru, Bukit Tambun), off the central States of Perak (Kerian, Kuala Trong) and Selangor (Sungai Besar, Kuala Selangor), and off the southern State of Johor (Parit Raja, Parit Sakai, Parit Besar) (Figure 1).

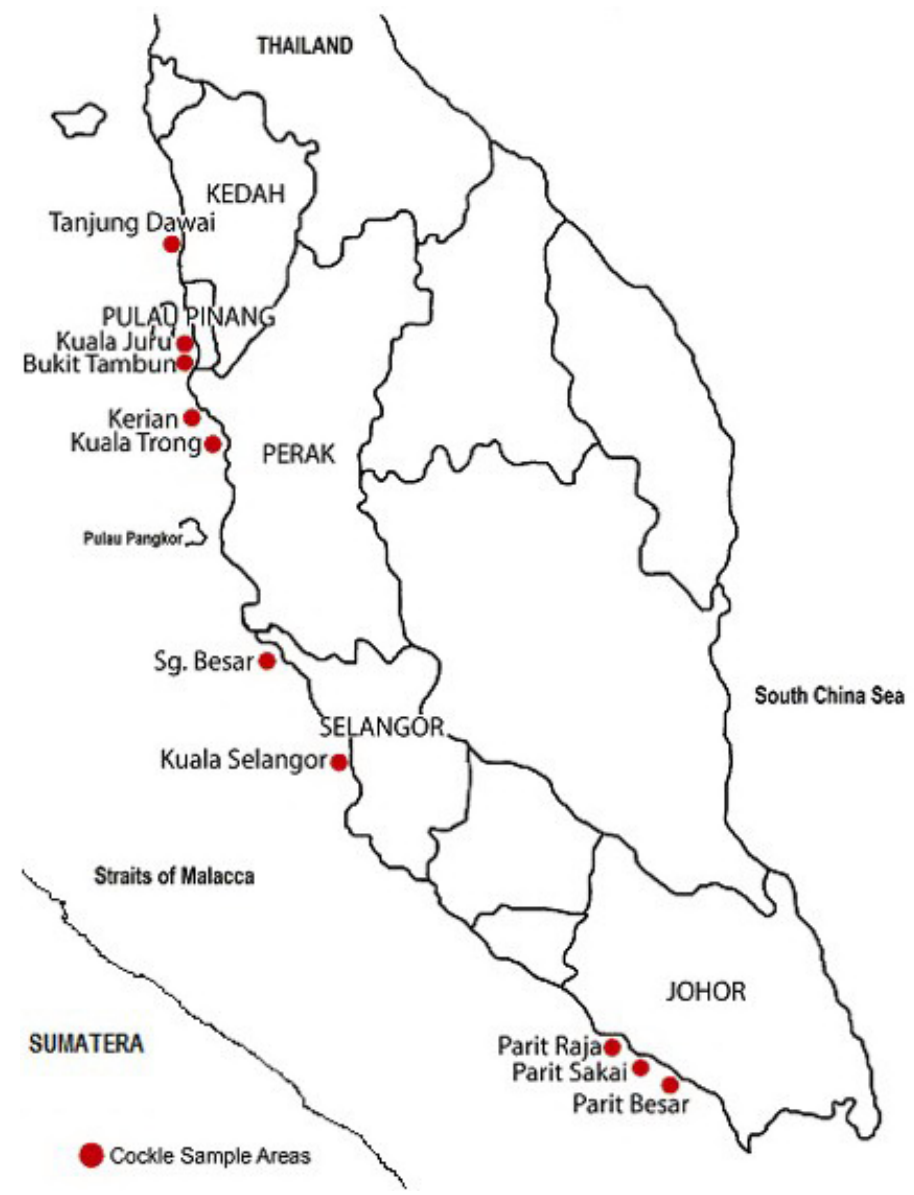

Figure 1. Anadara granosa sample areas in Peninsular Malaysia. 


\section{RAPD}

DNA was extracted from $100 \mu \mathrm{L}$ TNES-preserved mantle tissue using the AquaGenomic $^{\mathrm{TM}}$ kit. DNA amplification was done in a $25-\mu \mathrm{L}$ reaction mixture containing $2.5 \mu \mathrm{L}$ 10X PCR buffer (Bioron), $1.0 \mu \mathrm{L} 10 \mathrm{mM}$ deoxynucleotide (dNTP), $1.7 \mu \mathrm{L} 100 \mathrm{mM}$ $\mathrm{MgCl}_{2}, 1.5 \mu \mathrm{L}$ primer, $0.2 \mu \mathrm{L} 5 \mathrm{U}$ Taq polymerase (Bioron) and $3.0 \mu \mathrm{L}$ template DNA. Amplifications were performed in a PTC-200 Peltier thermocycler, which was programmed for 40 cycles: 4 initial cycles of $3 \mathrm{~min}$ each at 94,36 and $72^{\circ} \mathrm{C}$, followed by 35 cycles of $30 \mathrm{~s}$ at $94^{\circ} \mathrm{C}, 1 \mathrm{~min}$ at $36^{\circ} \mathrm{C}$, and 2 min at $72^{\circ} \mathrm{C}$, and a final amplification of 1 cycle of $30 \mathrm{~s}$ at $94^{\circ} \mathrm{C}, 1 \mathrm{~min}$ at $36^{\circ} \mathrm{C}$ and $10 \mathrm{~min}$ at $72^{\circ} \mathrm{C}$ (Patwary et al., 1994). During the preliminary tests, 40 oligonucleotide primers (Operon Techonologies, Inc.) from the OPC and OPG kits (Bio Basic Inc.) were screened for each population. Ten primers were selected from this panel based on their ability to amplify reproducible and easily scorable DNA bands. These 10 primers were then screened for informative polymorphisms among a greater number of individuals from the populations tested, and five primers were selected for subsequent use in the population analysis. These primers were (5'- to -3'): OPC7 (-gtc-ccg-acg-a-), OPC-14 (-tgc-gtg-ctt-g-), OPG-8 (-tca-cgt-cca-c), OPG-10 (-agg-gcc-gtc-t-), and OPG-19 (-gtc-agg-gca-a-). Amplified products were then separated on 1.5\% agarose gels run in $0.5 \mathrm{X}$ TBE buffer, stained with ethidium bromide and observed under UV light for the detection of successful amplification.

\section{Mitochondrial DNA}

DNA amplification was conducted in a $25-\mu \mathrm{L}$ reaction mixture containing $2.5 \mu \mathrm{L} 10 \mathrm{X}$ PCR buffer (Bioron), $0.5 \mu \mathrm{L} 10 \mathrm{mM}$ deoxynucleotide (dNTP), $0.75 \mu \mathrm{L} 100 \mathrm{mM} \mathrm{MgCl}, 0.8$ $\mu \mathrm{L}$ of each forward (5'-CWA-ATC-AYA-AAG-ATA-TTG-GAA-C-3') (Colgan et al., 2003) and reverse (5'-AAT-ATA-WAC-TTC-WGG-GTG-ACC-3') primer, $0.3 \mu \mathrm{L} 5$ U Taq polymerase (Bioron) and $1.5 \mu \mathrm{L}$ template DNA. The amplifications were performed in a PTC-200 Peltier thermocycler, which was programmed for 31 cycles: $30 \mathrm{~s}$ at $95^{\circ} \mathrm{C}, 45 \mathrm{~s}$ at $43^{\circ} \mathrm{C}$ and $1 \mathrm{~min}$ at $72^{\circ} \mathrm{C}$ (Colgan et al., 2003). This was followed by the purification of excised fragments by the EZ-10 Spin Column DNA Gel Extraction kit (BioBasic Inc.) prior to sequencing. The amplified DNA was directly sequenced using an automated DNA sequencer (ABI 3730 XL Genetic Analyzer).

\section{Data analysis}

\section{$R A P D$}

Pooled data for all primers were utilized for the construction of a single data set for the estimation of polymorphic loci, heterozygosity levels, number of alleles, interpopulation genetic similarity, and distance values based on unbiased minimum distance (Nei, 1978), as well as a dendrogram using the unweighted pair group method with arithmetic mean (UPGMA). This was done using the Tools for Population Genetic Analyses (TFPGA; Miller, 1997) software. Population differentiation, $F_{\mathrm{ST}}$ and the $95 \%$ confidence interval (CI) were calculated by bootstrapping over loci with 100 replications. In addition, correlation between the genetic and geographical distances was determined via the Mantel test (Mantel, 1967) using the same software. The Shannon index, which measures gene diversity and gene flow among 
populations, was calculated using the POPGENE ver. 1.32 software (Yeh et al., 1999). To visualize the multidimensional relationships of the samples, a principal coordinate analysis (PCO) scatter plot was built using the Multivariate Statistical Package ver. 3.1 (MVSP) software.

\section{$m t D N A$}

All aligned sequences (MEGA 4) were collapsed to unique haplotypes or sequences using the Collapse-1.2 software (Posada, 2004). The nucleotide diversity $(\pi)$, the haplotype diversity $(h)$, the number of polymorphic sites and haplotypes, and population divergence were estimated using the Arlequin ver. 3.11 software (Excoffier et al., 2005). Two tests of neutrality were also conducted using this program to determine whether the sequenced populations deviated from a neutral equilibrium model. The two tests were Tajima's $D$ (Tajima, 1989) and $\mathrm{Fu}$ and $\mathrm{Li}$ 's $F$ (Fu and $\mathrm{Li}, 1993)$. The phylogeographic relationships were inferred using the maximum parsimony (MP) and neighbor-joining methods derived from the two-parameter equation of Kimura (1980) in MEGA 4. A Mantel test was also performed to determine the correlation between genetic and geographic distances using TFPGA. Finally, the nuclear RAPD and mtDNA data were also compared using a Mantel test.

\section{RESULTS}

\section{Genetic variability}

\section{RAPD}

Based on the screening procedure, 5 primers were selected for population studies. The primers were OPC-07, OPC-14, OPG-08, OPG-10, and OPG-19. Thirty-five polymorphic bands were generated with each primer producing seven bands. OPC-07 generated bands ranging from $\approx 150$ to $700 \mathrm{bp}$, OPC-14 from $\approx 330$ to $900 \mathrm{bp}$, OPG-08 from $\approx 180$ to $700 \mathrm{bp}$, OPG-10 from $\approx 480$ to $1500 \mathrm{bp}$, and OPG-19 from $\approx 480$ to $1400 \mathrm{bp}$. The total scoring range was between $\approx 150-1500$ bp.

Generally, all populations had high levels of polymorphism ranging from 0.94 to 1.00 . However, heterozygosity values were low, ranging from 0.37 to 0.45 (Table 1 ). The Shannon index, measuring gene diversity over all loci, was $0.549 \pm 0.056$. The Nei (1973) gene diversity generated showed a mean of $0.485 \pm 0.043$ and the average gene flow $\left(\mathrm{N}_{\mathrm{m}}\right)$ value was 9.5231 .

\begin{tabular}{|c|c|c|c|c|c|c|c|c|c|c|}
\hline \multirow[t]{2}{*}{ Parameter } & \multicolumn{3}{|c|}{ North } & \multicolumn{4}{|c|}{ Central } & \multicolumn{3}{|c|}{ South } \\
\hline & TD & BT & JA & $\mathrm{KP}$ & KT & SB & KS & PSJ & PRJ & PBJ \\
\hline$\%$ Polymorphic loci & 0.94 & 0.94 & 0.94 & 1.00 & 1.00 & 1.00 & 1.00 & 1.00 & 1.00 & 0.97 \\
\hline Average heterozygote(s) over all loci & 0.42 & 0.40 & 0.41 & 0.37 & 0.44 & 0.39 & 0.37 & 0.42 & 0.45 & 0.41 \\
\hline
\end{tabular}

$\mathrm{TD}=$ Tanjung Dawai; BT $=$ Bukit Tambun, and JA = Kuala Juru, in North Peninsula. KP $=$ Kerian; KT $=$ Kuala Trong; KS = Kuala Selangor, and SB = Sungai Besar, in Central. PBJ = Parit Besar; PRJ = Parit Raja, and PSJ = Parit Sakai, in South Peninsula, Malaysia. Shannon index $=0.549 \pm 0.056$; mean Nei's (1973) gene diversity $=$ $0.485 \pm 0.043 ; \mathrm{N}_{\mathrm{m}}$ (average gene flow value $)=9.523$. 


\section{mtDNA sequencing}

After the exclusion of gaps and ambiguous sites adjacent to gaps, the final length of the aligned sequence was $585 \mathrm{bp}$. Of the 150 sequences, 22 haplotypes were generated and the sequences have been deposited in GenBank with accession numbers from FJ411459 to FJ411480. Each population had haplotypes varying from 1 to 5, with an average of 4 (Table 2). Nucleotide diversity ranged from 0 to 0.010 with an average of 0.003 . The highest haplotype diversity was found in the southern population of Parit Raja (0.829), whereas the lowest haplotype diversity was found in Sungai Besar, in the central region (0.000). The average number of polymorphic sites per population was 6. Overall, Juru, Kuala Selangor, Parit Raja, and Parit Besar had the highest variability in terms of all four diversity measures compared to the rest (Table 3). Although most of the populations had a common haplotype, Hap01, they also tended to form their own unique haplotypes albeit at very low frequencies (most were through a single or a few substitutions). However, Kuala Trong, Kuala Juru, Parit Sakai, and in particular Parit Raja and Parit Besar had much lower frequencies of Hap01. In fact, some of the unique haplotypes for Parit Raja, Parit Besar and Juru showed a considerably higher number of substitution sites.

\section{Genetic structuring}

\section{$R A P D$}

The dendrogram (Figure 2), generated based on Nei (1978) genetic distances, indicated the segregation of the 10 populations into two clusters: Kerian (Perak - Central), Sungai Besar (Selangor - Central), Kuala Selangor (Selangor - Central), and Parit Besar (Johor South) formed one cluster, while the populations from Tanjung Dawai (Kedah - North), Bukit Tambun (Penang - North), Kuala Juru (Penang - North), Kuala Trong (Perak - Central), Parit Sakai, and Parit Raja (Johor - South) formed the other cluster.

The PCO plot supported the dendrogram, clearly illustrating that the cockles found off the west coast of Peninsular Malaysia were not genetically structured according to geographical regions based on nuclear RAPD markers (Figure 3). Although the $F_{\mathrm{ST}}$ value over all loci of $0.039 \pm 0.006$ revealed that there were significant differences between populations, this did not correlate with geographic distance as illustrated by the Mantel test $(\mathrm{r}=0.0340, \mathrm{P}=0.300)$.

\section{mtDNA sequencing}

Based on $F_{\mathrm{ST}}$ values after sequential Bonferroni's corrections (to minimize type 1 error rates), levels of differentiation were generally low except between the Parit Raja and Parit Besar populations in the south with the rest of the populations, apart from Kuala Trong (Central) and Juru (North). Similarly, Kuala Trong was also differentiated from most of the other populations. Sungai Besar was significantly differentiated from this group of four populations. The other southern population of Parit Sakai was, however, more closely related to the central and northern populations. For tests on neutrality, only the Kerian and Kuala Selangor populations showed significant departure with Tajima's $D$, whereas $\mathrm{Fu}$ and $\mathrm{Li}$ 's $F$ was not significant in all populations (data not shown). 
Molecular markers for conservation of blood cockles

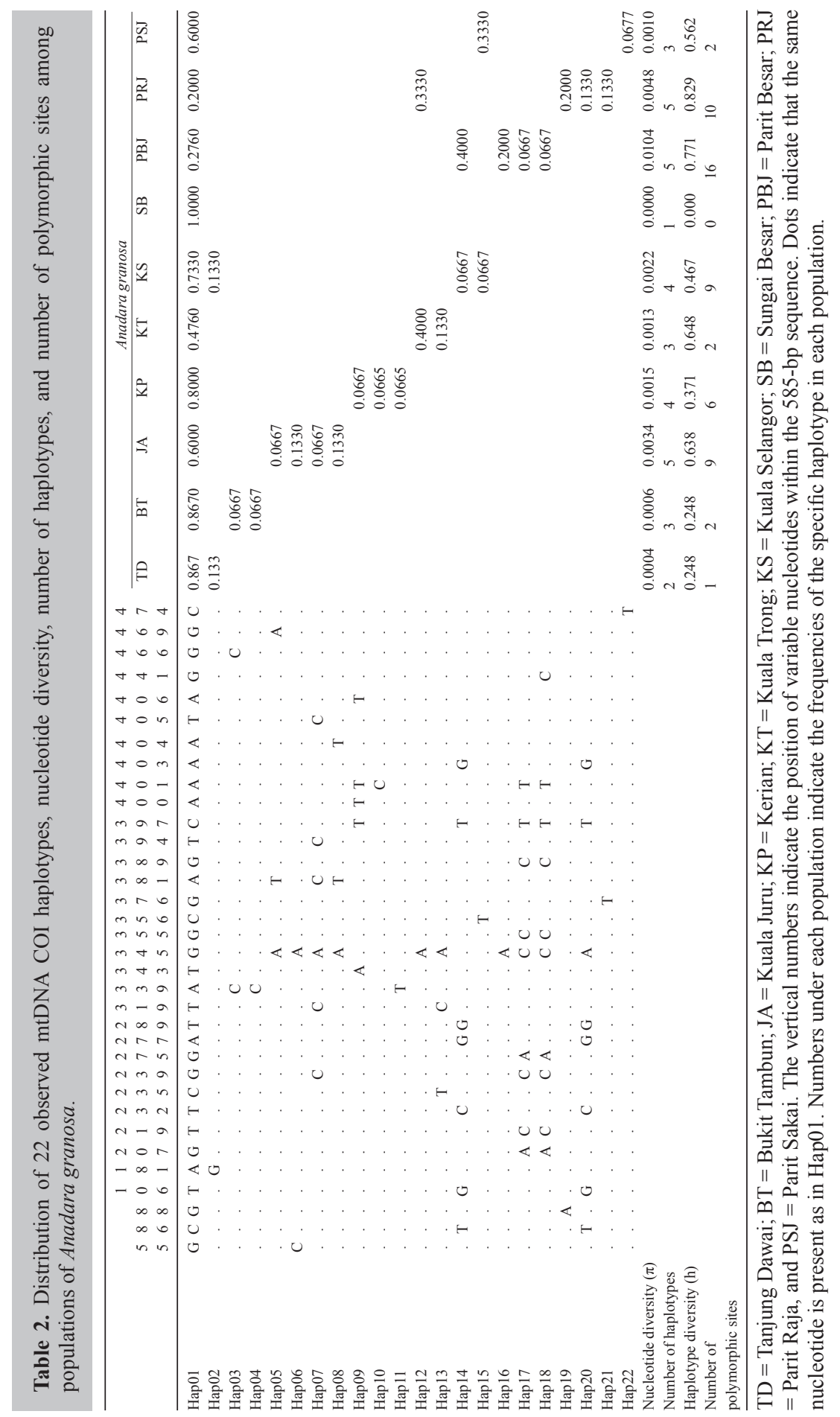


Table 3. Pairwise Nei's (1978) distance measure (above diagonal) of RAPD data and population divergence between samples $\left(F_{\mathrm{ST}}\right)$ and within population based on mtDNA COI sequence data for Anadara granosa.

\begin{tabular}{|c|c|c|c|c|c|c|c|c|c|c|}
\hline \multirow[t]{2}{*}{ Site } & \multicolumn{3}{|c|}{ North } & \multicolumn{4}{|c|}{ Central } & \multicolumn{3}{|c|}{ South } \\
\hline & TD & $\mathrm{BT}$ & JA & $\mathrm{KP}$ & KT & $\mathrm{KS}$ & SB & PBJ & PRJ & PSJ \\
\hline TD & 0.0000 & 0.0135 & 0.0270 & 0.0729 & 0.0165 & 0.0840 & 0.0770 & 0.0282 & 0.0120 & 0.0743 \\
\hline BT & -0.014 & 0.0000 & 0.0163 & 0.0365 & 0.0282 & 0.0550 & 0.0481 & 0.0278 & 0.0234 & 0.0507 \\
\hline JA & 0.077 & 0.068 & 0.0000 & 0.0549 & 0.0244 & 0.0498 & 0.0475 & 0.0212 & 0.0235 & 0.0482 \\
\hline KP & -0.009 & -0.025 & 0.029 & 0.0000 & 0.0502 & 0.0135 & 0.0144 & 0.0469 & 0.0722 & 0.0269 \\
\hline KT & $(0.248)^{*}$ & $(0.240)^{*}$ & 0.107 & 0.187 & 0.0000 & 0.0621 & 0.0565 & 0.0345 & 0.0177 & 0.0517 \\
\hline KS & -0.030 & 0.007 & 0.013 & -0.014 & 0.153 & 0.0000 & 0.0031 & 0.0435 & 0.0780 & 0.0127 \\
\hline SB & 0.071 & 0.036 & $(0.202)^{*}$ & 0.071 & $(0.393)^{*}$ & 0.125 & 0.0000 & 0.0548 & 0.0839 & 0.0182 \\
\hline PBJ & $(0.337)^{*}$ & $(0.331)^{*}$ & 0.161 & $(0.274)^{*}$ & $(0.190)^{*}$ & $(0.204)^{*}$ & $(0.474)^{*}$ & 0.0000 & 0.0330 & 0.0677 \\
\hline PRJ & $(0.349)^{*}$ & $(0.343)^{*}$ & 0.167 & $(0.286)^{*}$ & 0.046 & $(0.241)^{*}$ & $(0.482)^{*}$ & 0.155 & 0.0000 & 0.0283 \\
\hline PSJ & 0.157 & 0.147 & 0.063 & 0.103 & 0.160 & 0.044 & $(0.298)^{*}$ & $(0.206)^{*}$ & $(0.210)^{*}$ & 0.0000 \\
\hline
\end{tabular}

$\mathrm{TD}=$ Tanjung Dawai, Kedah; BT = Bukit Tambun, Penang; JA = Kuala Juru, Penang; KP = Kerian, Perak; KT = Kuala Trong, Perak; KS = Kuala Selangor, Selangor; SB = Sungai Besar, Selangor; PBJ = Parit Besar, Johor; PRJ $=$ Parit Raja, Johor, and PSJ $=$ Parit Sakai, Johor. *Significant probabilities $(\mathrm{P}<0.05)($ after sequential Bonferroni's corrections) are indicated in parentheses. $F_{\mathrm{ST}}$ over all loci $=0.0391 \pm 0.0062$ for RAPD data; Mantel test $(\mathrm{r})=$ $0.0340, \mathrm{P}=0.300$ for RAPD data; Mantel test $(\mathrm{r})=0.2710, \mathrm{P}=0.622$ for mtDNA data.

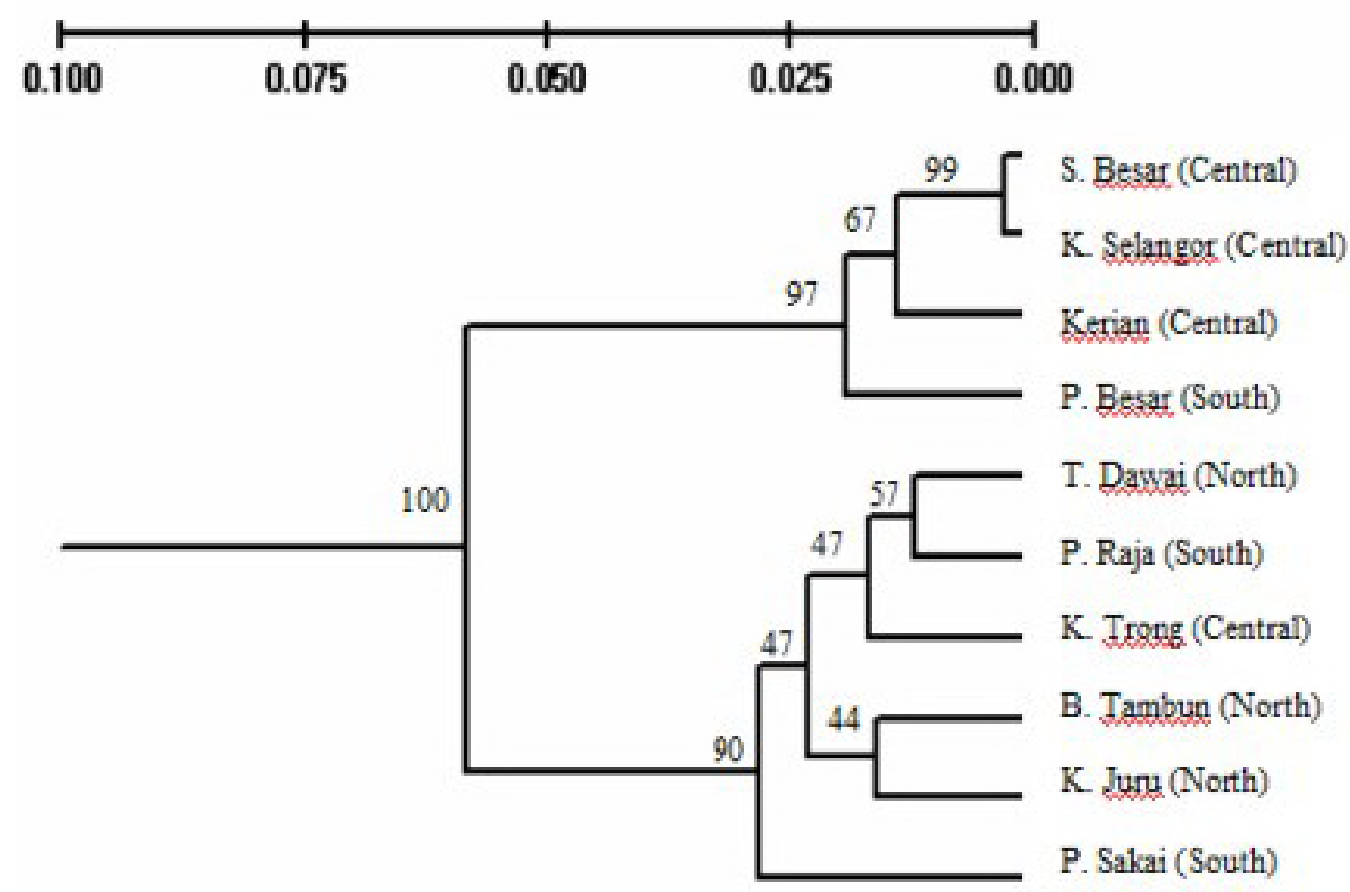

Figure 2. Dendrogram of Anadara granosa populations generated by UPGMA based on Nei's (1978) distance measure, summarizing data on differentiation according to RAPD analysis using TFPGA. Bootstrap values are generated using 1000 permutations. 


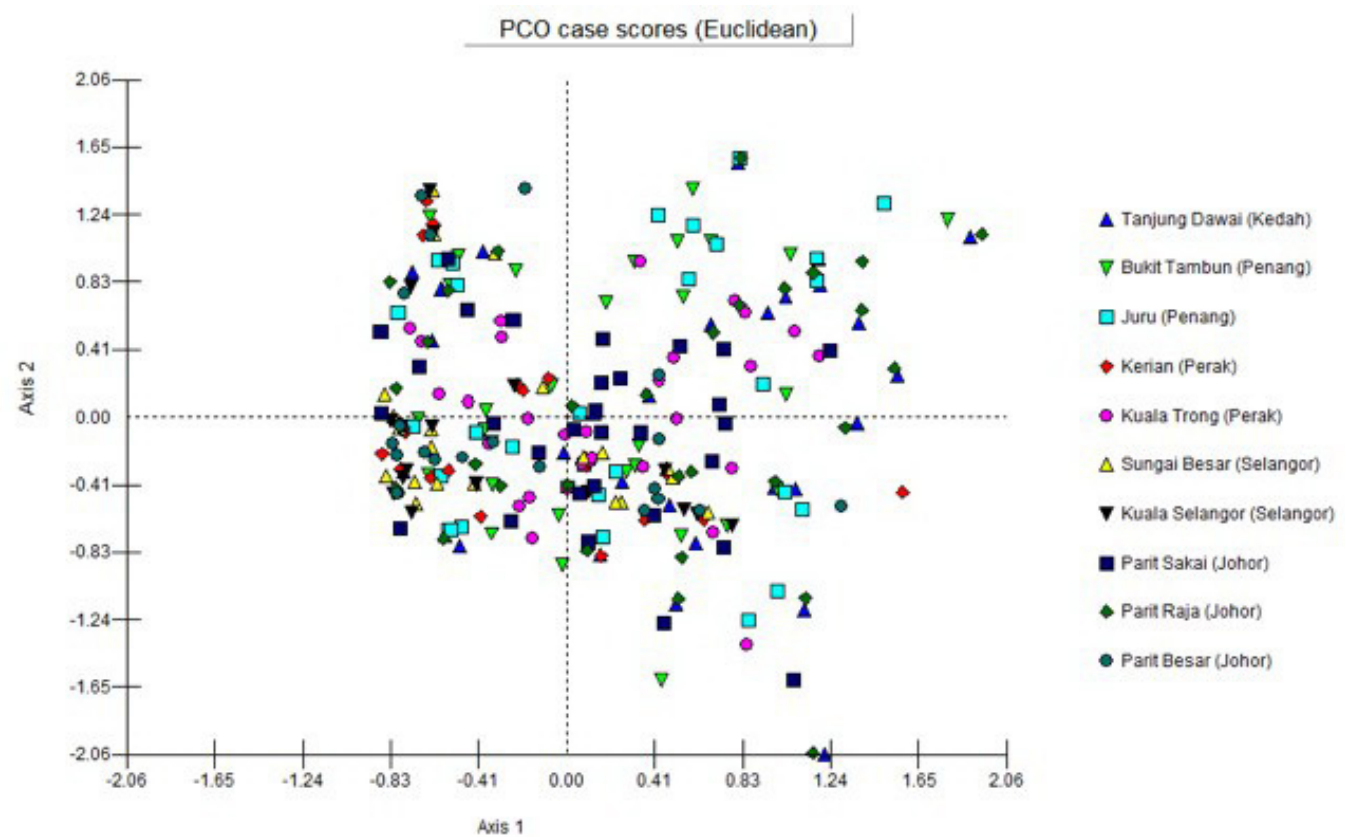

Figure 3. The ordination of 10 Anadara granosa population samples resulting from principal coordinate (PCO) analysis of a similarity matrix generated from 35 RAPD markers along the first and second principal axes.

The MP tree generated 5 clusters (Figure 4). The low bootstrap values at the internodes showed that the phylogenetic relationships were unstable. Several haplotypes were moderately to highly linked with each other. Examples were between haplotypes 03 and 04 (both from Bukit Tambun), haplotypes 10 and 11 (both from Kerian), haplotypes 14 and 20 (from Kuala Selangor and Parit Raja, respectively), haplotypes 05 and 08 (both from Kuala Juru), haplotypes 07 and 13 (from Kuala Juru and Kuala Trong, respectively), and haplotypes 17 and 18 (both from Parit Besar). Although populations overlap in general, there was some indication of closer genetic relationships of haplotypes found in the same geographic locality. The Mantel test showed a positive but nonsignificant correlation between geographic and genetic distances $(\mathrm{r}=0.2710, \mathrm{P}=0.622)$, as in the RAPD analysis (Table 3 ).

The minimum spanning network (MSN) analysis confirmed the dominance of Hap01, being represented in all populations sampled. In fact, the Sungai Besar (Central) population was made up entirely of this haplotype. The second most dominant haplotype was Hap12, which contained individuals from Kuala Trong (Central) and Parit Besar (South), followed by Hap14 and Hap15. The rest of the haplotypes were unique to a particular population. Most represent a single or a few base substitutions for one of the two most common haplotypes. 


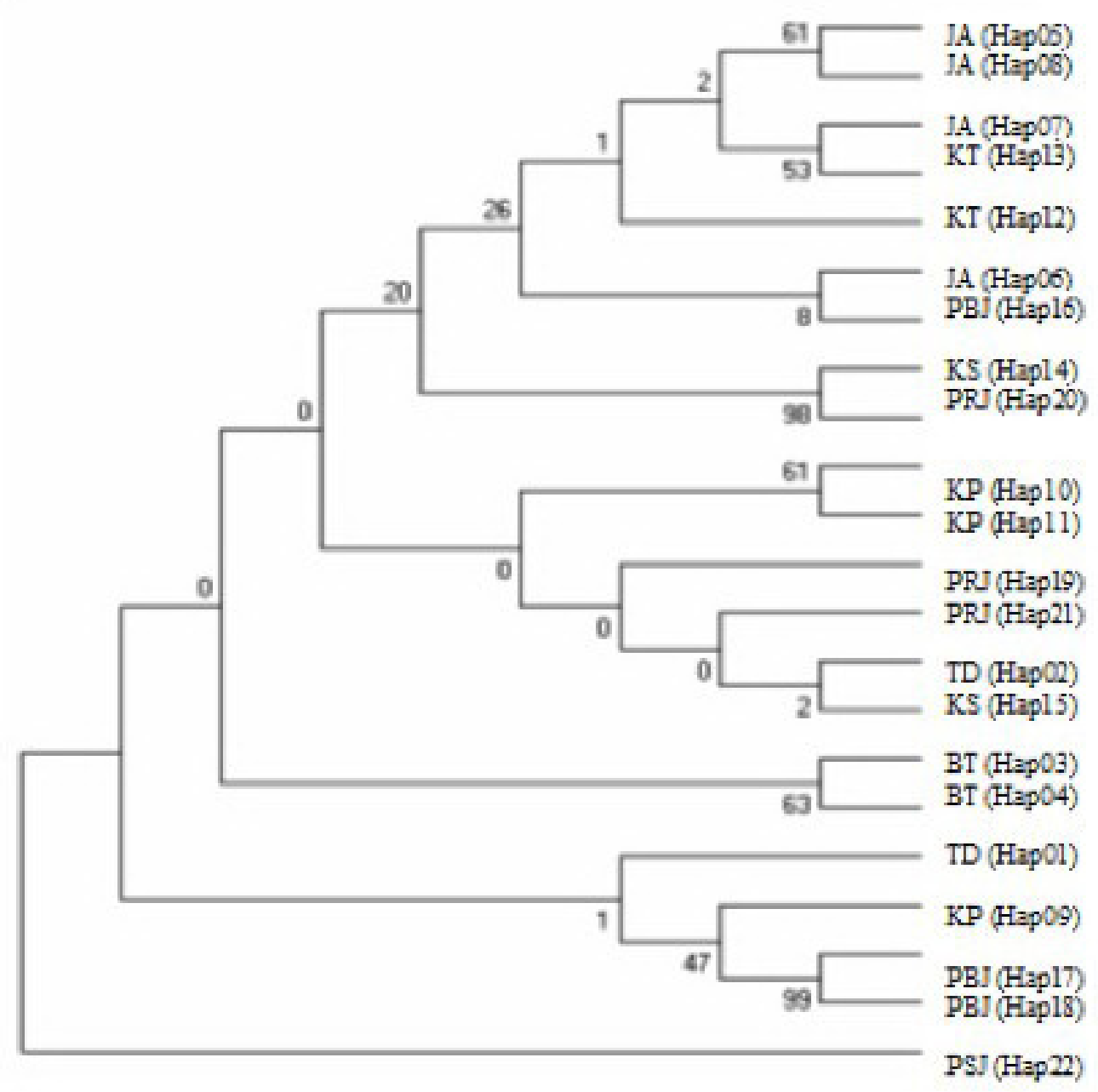

Figure 4. Evolutionary relationships of 22 haplotypes inferred using the maximum parsimony method with 500 replicates. $\mathrm{TD}=$ Tanjung Dawai; $\mathrm{BT}=$ Bukit Tambun; JA $=$ Kuala Juru; KP $=$ Kerian; KT $=$ Kuala Trong; KS = Kuala Selangor; PBJ = Parit Besar; PRJ = Parit Raja, and PSJ = Parit Sakai.

\section{DISCUSSION}

\section{Levels of genetic variability}

The nuclear RAPD data revealed mean heterozygosity values $<50 \%$. As steps were taken to ensure reproducibility, technical errors could not have been a reason for this observation. According to Luttikhuizen (2003), heterozygote deficiencies are common in bivalves. The proposed causes included population mixing, differential selection acting on larvae or adults, genomic imprinting, and null alleles. Considering the extensive larval recruitment ability of this species, population mixing is the most probable factor. The other factors, however, 
could not be tested with the present data. However, high gene diversity over all loci was observed (Shannon index $=0.549 \pm 0.056$ and Nei (1973) gene diversity $=0.4852 \pm 0.0430$ among 35 loci), which is advantageous for the sustainability, management, and the stability of the species as a major commodity in the fishery sector. Tang et al. (2005) found a similarly high Nei's genetic diversity in the tropical abalones (Haliotis asinina) in the Gulf of Thailand and the Andaman Sea, ranging from 0.54 to 0.61 , which they attributed to a relatively large number of founders. This is crucial for establishment of selective breeding and conservation programs.

The high overall gene diversity was most probably attributed to the movement of the northwesterly oceanic current, which flows through the Straits of Malacca. The cockle larvae, which are planktonic, are easily mobilized by the current and carried along before settling on a suitable substrate. This allows mixing of populations leading to a Wahlund effect, which could also explain the low heterozygosity within population. Upon reaching a suitable natural substrate, the spats settle. At this stage, they are sedentary and thereby exposed to changes in salinity and water quality, leading to diversification into different gene pools. Such attributes may lead to an increase in gene diversity over time ensuring the sustainability of the cockle populations. During the next reproductive cycle, larvae from the previous generations repeat the process of gene homogenization (if other factors do not come into play). However, the spats are also exposed to human elements when culturists harvest them to be translocated to culture beds.

\section{General lack of genetic structuring}

\section{$R A P D$}

Both the RAPD and COI data showed lack of structuring. This was more obvious in the RAPD data. For these nuclear markers, similarity was highest between the two central populations of Sungai Besar and Kuala Selangor, which could be explained by either gene flow between two adjacent populations or common origin due to the sharing of the same source of spats. However, the hypothesis of isolation by distance breaks down when considering differentiation among other populations. Many of the northern and central populations overlap with the southern populations of Johor.

\section{mtDNA sequencing}

As with the RAPD data, there was a general lack of differentiation, extending from the northern region of Tanjung Dawai to Sungai Besar in Selangor (central Peninsula Malaysia) and including the southern Parit Sakai population in the mtDNA data. The two southern populations of Parit Besar and Parit Raja were, however, well differentiated and to a lesser extent Kuala Trong (central). MSN highlighted the presence of a common haplotype Hap01 throughout (except for Parit Raja, Parit Besar, Kuala Trong, and Kuala Juru) but with evidence of independent evolution, albeit slight branching of unique haplotypes (Figure 5). This was supported by the dendrogram, which revealed many individuals of different populations overlapping with no observed clade assemblages bounded by geographical localities. The star-like topology showed that new haplotypes had radiated by base mutations from an ancestral hap- 
lotype, Hap01. Mahidol et al. (2007) found a similar star-like topology while studying Asian moon scallops, Amusium pleuronectes, leading to the conclusion of no significant genetic structure for this species within the Gulf of Thailand.

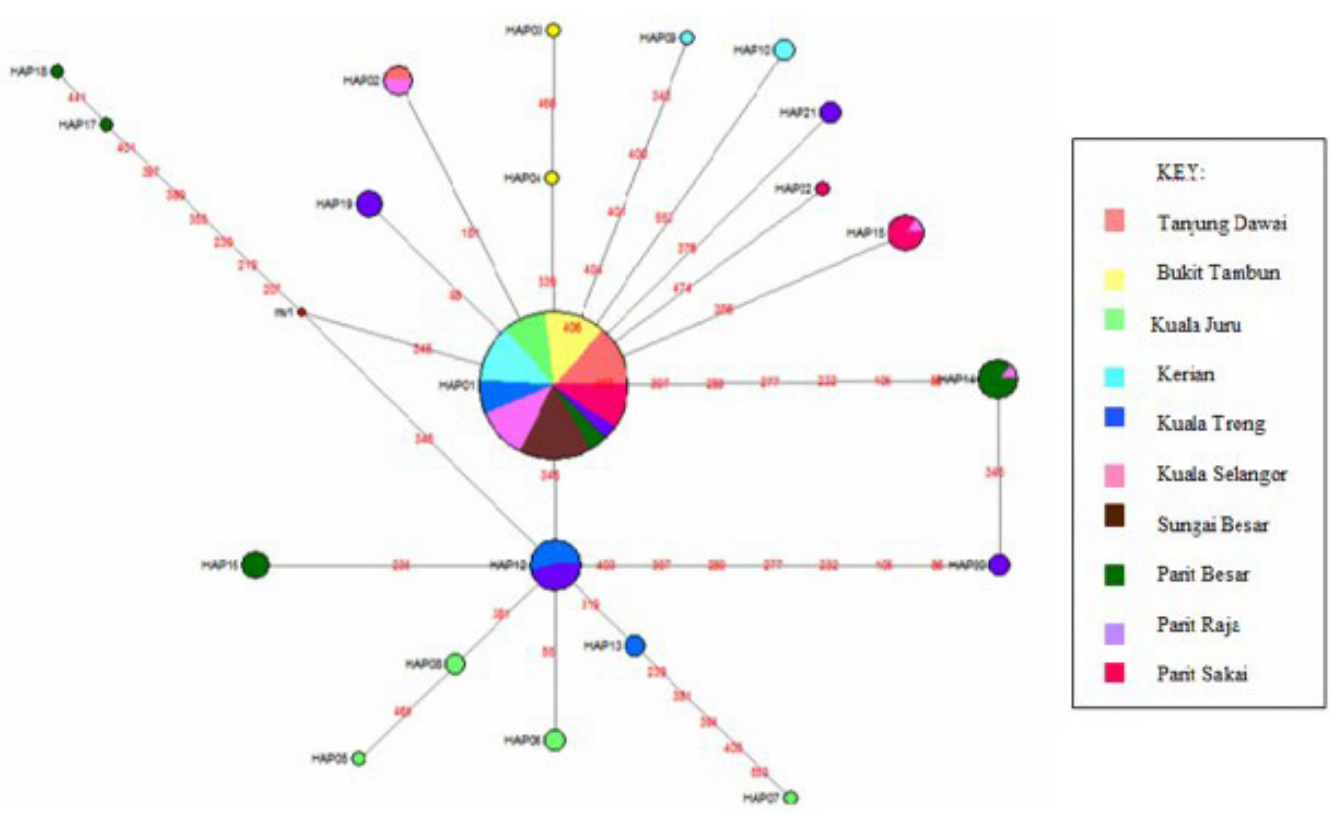

Figure 5. Minimum spanning network showing relationships among 22 Anadara granosa COI haplotypes. The numbers indicate mutation sites between the haplotypes.

The low interpopulation diversity in both marker types is consistent with other studies on marine organisms such as that by Aranishi and Okimoto (2005) on Pacific oysters. As observed in other bivalve studies, the pelagic state of the cockle larvae allows extensive migrating ability. In addition to its pelagic larval life history, passive transport of the A. granosa larvae by ocean currents in the Straits of Malacca, which flow southwards from the north, was another likely factor for the homogeneity observed. According to a study done by Hii et al. (2006), the northern waters of the Straits of Malacca circulate and collide with the southern waters in the coastal waters off Lumut (Central), Klang (Central) and southern Johor (South). They also added that the current movement in the Straits is complex and unstable due to its narrow stretch and shallow waters. Therefore, the circulating current carrying the larvae to the different areas along the coast of Peninsular Malaysia could cause the lack of differentiation among geographical regions.

Numerous observations of ocean current-mediated gene flow have been documented including study done by Pineda et al. (2007) on fish and shellfish. Fernández-Tajes et al. (2007) working on razor clams in Spain, Portugal, and Ireland also suggested that the homogeneity observed in their studies was due to the passive transport of larvae along the coast occurring over long distances as a result of oceanic currents. The $\mathrm{N}_{\mathrm{m}}$ value of 9.5 observed for RAPD data in our study provided further support that there was high gene flow among all the 
populations sampled. According to Tremblay and Ackerman (2001), an $\mathrm{N}_{\mathrm{m}}$ value exceeding 1 is potentially high enough for gene flow to prevent substantial differentiation due to drift and natural selection. Star et al. (2003) who investigated the greenshell mussel, Perna canaliculus, in New Zealand, also obtained similarly high values. The high gene flow observed here confirmed that the sample size chosen was acceptable.

Human-mediated transfer of cockle spats for farming reasons could be another important factor for the lack of structuring. This is known to commonly occur in the Malaysian cockle industry, but unfortunately, poor record keeping does not allow us to substantiate this hypothesis of population comparisons. Graham et al. (2005) employed multivariate analyses to investigate the spatial distribution of macrobenthos and the effects of farming towards the macrobenthic community. Organic farm wastes seem to have caused low macrofaunal species richness and loss of species, and assemblages recovering from organic waste impacts would possess fewer species than assemblages progressing towards grossly polluted status. They found this method to be useful in determining the phylogeography of their specimens but suggested that future investigations should include broad-scale change over a number of years as type 1 errors could possibly occur. They also noted that external factors such as current movement and sedimentation play a conspicuous role in determining the distribution of the macrobenthos and may reflect changes in the overall community composition, which is most likely the scenario for the Malaysian cockles.

However, the mtDNA data revealed some structuring but not related to geographic distance. The southern populations of Parit Raja and Parit Besar and to a lesser extent Kuala Trong (central) were highly differentiated from the rest of the populations. Kuala Juru was also included in this group, although in general it was genetically homogeneous with the rest except Sungai Besar. The variability involving these populations may be a consequence of various reasons: 1) barrier to larval dispersal between the northern and the southern populations allowing for independent evolution of the adults in the maternal line, which was not detected by the RAPD markers, or 2) effects of adverse conditions such as environmental perturbation. The former would, however, only affect the southern populations in relation to the rest.

The more obvious reason to account for the relative dissimilarity between the southern populations of Parit Raja, Parit Besar and the rest would be limited dispersal due to one or several factors. A break in the coastal continuum and the complexity of local current systems, which may retard larval dispersal, could also explain the heterogeneity observed. Oceanographic (currents) and topographical features, physical barriers, and spatio-temporal spawning time are some of the factors that have been proposed to prevent gene flow between adjacent and contiguous populations of marine species. It is generally believed that the one-fathom deep waters along the coast act as a barrier to the free movement of many species of fish, and the majority of them could only be found $4-5 \mathrm{~m}$ off the sea floor (Trenkel et al., 2004). Whether this also applies to the A. granosa should be investigated by more intensive sampling at locations between Sungai Besar and the south. According to the Fisheries Department (personal communication) there are no A. granosa cockle beds along this area because of strong winds, which churn up the bottom, disallowing the transplanting of cockles for culture.

Many fish cage culture activities in Malaysia are carried out in the coastal aquatic environments such as lagoons or other kinds of brackish water bodies in which conditions are suitable for breeding. However, some of these water bodies are subjected to severe pollution from various sources - land and industrial wastes and oil spillage. For example, in 1987, high 
levels of pollution from municipal wastes were reported (Basiron, 1995) off the coast of Johor in the Straits of Malacca, where Parit Raja and Parit Besar are located. According to the newsletter, this adversely affected the coastal waters, and high levels of pollutants were detected in the cockles, leading to their ban for consumption during that period. As a consequence, cage operators in Johor lost US $\$ 204,081$ worth of production during that period.

Chung et al. (2008) investigated the effect of toxicants on the genetic variation of amphipods in the Panama River. These toxicants may cause DNA damage, which can lead to genetic variation by either increasing the rate of mutation or decreasing the amount of variability due to the purging of maladapted genomes as suggested by De Wolf et al. (2004). Their study focused on the mollusk Littorina littorea in the Scheldt estuary, which had been subjected to heavy metal pollution such as $\mathrm{Cd}, \mathrm{Cu}, \mathrm{Cr}, \mathrm{Fe}$, and $\mathrm{Ni}$, all known to be mutagenic. In their study, they found that genetic variability was not due to ecophysiologically induced phenotype expression but direct mutagenic activity in metal-polluted sites. Although they suggested that DNA damage research is needed to investigate their hypothesis, selection and/or bottlenecks, either related to mutagenic, physiological and/or ecological effects, could also be implicated. A bottleneck is known to affect most loci, reducing their heterozygosity and polymorphism levels, while selection is expected to affect only particular loci (Belfiore and Anderson, 2001).

Bearing in mind that the evidence is only speculative at this moment, it would appear that these populations may be under selective pressure, as overall variability and frequencies of unique haplotypes were relatively high. It is also worth noting that while the pollution status of the Kuala Trong population is unknown, the Kuala Juru is heavily exposed to industrial wastes (Shazili et al., 2006). However, both Tajima's and Fu and Li's tests of neutrality did not detect any evidence of selective pressure for the COI gene for these polluted populations. In fact, departure was instead observed for the Kerian and Kuala Selangor populations. This is more likely to reflect a population level effect such as drift due to small population size or incomplete sampling rather than selection acting on mtDNA, which is revealed by Tajima's but not by the more robust analysis of Fu and Li's. The southern Parit Sakai population, however, showed homogeneity with other populations, which cannot be attributed to pollution or isolation from the more northern populations. However, as stated above, human-mediated translocation is common in this industry, and the data for Parit Sakai may be an illustration of this.

mtDNA analysis also revealed the monomorphism of Sungai Besar, strongly indicating bottlenecking. Bottlenecks are caused by a few factors such as: 1) low number of breeding females in the area; 2) small number of breeders (founder effect) in hatchery-reared commercial stocks; 3 ) inbreeding, which could lead to the loss of genetic variability, and 4) reduced population due to harvesting pressure. This highlights the importance of genetics in minimizing the effects of bottlenecks in aquaculture as illustrated by Gaffney (2006) in his study on shellfish, particularly oysters. According to Gaffney (2006), molecular genetic tools can be used to effectively monitor restoration programs, deploy enhancement stocks to recover degraded wild populations and reverse the negative effects of long-term selective harvesting.

Comparison of the two methods highlights the importance of a multi-approach study in population genetics. The RAPD method proved to be useful in obtaining new genetic information on nuclear markers for the A. granosa, which had not been previously documented. Although a dominant marker, it provided important information, which complemented mtDNAsequencing data. In this study, the RAPD method revealed that this cockle species of Peninsular Malaysia was relatively homogeneous. This largely agreed with the sequencing data, but the 
COI gene, not observed in the former, showed a degree of population structuring. Neither the RAPD analysis $(\mathrm{r}=0.0340, \mathrm{P}=0.300)$ nor the $\mathrm{mtDNA}$ analysis $(\mathrm{r}=0.2710, \mathrm{P}=0.622)$ showed strong correlations with geographical distances, as estimated by the Mantel tests. However, a slightly higher value in the mtDNA analysis revealed that there was differentiation involving a few populations, which could not be detected in the RAPD analysis. Several characteristics of mtDNA, e.g., higher mutation rates, lower effective sample size, and higher resolution compared to RAPD, renders it more sensitive to genetic variability assessment (Alexandre et al., 2002). However, further study needs to be done to confirm this by utilizing more efficient nuclear markers such as microsatellites. Another shortcoming of the RAPD data is its limited power of statistical analysis. On the other hand, more precise population assessment can be determined through sequencing data.

This study provides the first documented evidence of population genetics of $A$. grano$s a$ in Malaysia and affords useful data to strategize in long-term management and conservation of $A$. granosa, which would otherwise be compromised without sufficient analysis of the genetic diversity of the existing populations found along the west coast of Peninsular Malaysia. If the qualities of the cockles are affected by the amount of pollution in the Straits of Malacca, steps should be taken to monitor and ensure the health of their habitats. The results also showed high variability within this species as a whole. This is advantageous to ensure the survival of the species in harsh environments and their resistance to diseases, predators or other harmful physical factors.

Proper management of this important commodity is essential to ensure the survival of cockles, and their ability to adapt to sudden change in environment. Currently, there is limited application of genetics in aquaculture, and mechanisms for conserving the genetic diversity of farmed aquatic organisms are poorly developed in this country. The rapid expansion of aquaculture and the overexploitation of many capture fisheries have created conditions where irresponsible use of natural resources can result in adverse environmental and social impacts, inter-sectoral conflicts and unsustainability (FAO, 2007). Successful transition to more responsible, sustainable and productive aquaculture fisheries will largely depend on effective management of fishery genetic resources, and these resources will help determine the productivity of cultured and wild populations and their adaptability to environmental stresses such as human development and, more importantly at this time, climate change (FAO, 2007).

Having more detailed information on the genetics of blood cockles would give fishery managers a more precise and comprehensive view of the state of stocks under their stewardship and would allow them to schedule seasonal closures, catch quotas and other measures (Campbell, 2002). It would shed light on the interactions between cultured and wild species, an issue of increasing concern. In many cases, impacts of native aquatic diversity that have accidentally escaped from farms, or are intentionally stocked into the wild cannot be determined, because information on the genetic resources of both wild and farmed species is not known. Therefore, having such genetic information readily available and widely used in fishery management is important.

\section{ACKNOWLEDGMENTS}

We thank the staff members of the Fishery Research Institute for their assistance in providing information and cockle samples and in funding for this research. Universiti Sains 
Malaysia Fellowship also supported this project. We appreciate the helpful discussions with G. Chambers, T.T.T. Nguyen and the members of Lab 308.

\section{REFERENCES}

Alexandre WSH, Azeredo-Espin AML, Krieger MH and Krieger JE (2002). Mitochondrial DNA diversity in wild and cultured populations of Brycon opalinus (Cuvier, 1819) (Characiformes, Characidae, Bryconinae) from the Paraíba do Sul Basin, Brazil. Aquaculture 214: 81-91.

Aranishi F and Okimoto T (2005). Sequence polymorphism in a novel noncoding region of Pacific oyster mitochondrial DNA. J. Appl. Genet. 46: 201-206.

Basiron MN (1995). Managing Marine Pollution in the Straits of Malacca. Coastal Resources Management Project, Sri Lanka.

Belfiore NM and Anderson SL (2001). Effects of contaminants on genetic patterns in aquatic organisms: a review. Mutat. Res. 489: 97-122.

Campbell A (2002). Implications of genetic discrimination: Who should know what? Available at [mgm.stanford.edu/ biochem118/Projects/2002 OSP/Campbell.pdf]. Accessed February 20, 2009.

Chung PP, Hyne RV, Mann RM and Ballard JW (2008). Genetic and life-history trait variation of the amphipod Melita plumulosa from polluted and unpolluted waterways in eastern Australia. Sci. Total Environ. 403: 222-229.

Colgan DJ, Ponder WF, Beacham E and Macaranas JM (2003). Molecular phylogenetic studies of Gastropoda based on six gene segments representing coding or non-coding and mitochondrial or nuclear DNA. Moll. Res. 23: 123-148.

De Wolf H, Blust R and Backeljau T (2004). The population genetic structure of Littorina littorea (Mollusca: Gastropoda) along a pollution gradient in the Scheldt estuary (The Netherlands) using RAPD analysis. Sci. Total Environ. 325: 59-69.

Excoffier L, Laval LG and Schneider S (2005). Arlequin ver. 3.0: An integrated software package for population genetics data analysis. Evol. Bioinf. Online 1: 47-50.

FAO (Food and Agricultural Organization) (2006). Basic bivalve biology: taxonomy, anatomy and life history. [Online] Food and Agricultural Organization of the United Nation. Available at [http://www.fao.org/docrep/007/y5720e/ y5720e07.htm\#TopOfPage]. Accessed January 12, 2008.

FAO (Food and Agricultural Organization) (2007). The world's aquatic genetic resources: Status and needs. [Online] Food and Agricultural Organization of the United Nation. Available at [ftp://ftp.fao.org/ag/cgrfa/cgrfa11/r11w152e.pdf]. Accessed January 12, 2008.

Fernández-Tajes J, Gaspar M, Martínez-Patiño D, McDonough N, et al. (2007). Genetic variation of the razor clam Ensis siliqua (Jeffreys, 1875) along the European coast based on random amplified polymorphic DNA markers. Aquacult. Res. 38: 1205-1212.

Fu YX and Li WH (1993). Statistical tests of neutrality of mutations. Genetics 133: 693-709.

Gaffney PM (2006). The role of genetics in shellfish restoration. Aquat. Living Resour. 19: 277-282.

Graham JE, Macleod CK, Mawbey RB and Shields D (2005). Broad-scale effects of marine salmonid aquaculture on macrobenthos and the sediment environment in southeastern Tasmania. J. Exp. Mar. Biol. Ecol. 327: 70-90.

Hii YS, Law AT, Shazili NAM, Rashid MKA, et al. (2006). The Strait of Malacca: hydrological parameters, biological oxygen demand and total suspended solids. J. Sustainability Sci. Manag. 1: 1-14.

Kimura M (1980). A simple method for estimating evolutionary rates of base substitutions through comparative studies of nucleotide sequences. J. Mol. Evol. 16: 111-120.

Liu B, You F, Dong B and Xiang J (2006). The comparison between allozyme and RAPD markers for the population genetic structure analysis of scallop Chlamys farreri. Chinese J. Oceanol. Limnol. 24: 295-299.

Luttikhuizen PC, Drent J and Baker AJ (2003). Disjunct distribution of highly diverged mitochondrial lineage clade and population subdivision in a marine bivalve with pelagic larval dispersal. Mol. Ecol. 12: 2215-2229.

Mahidol C, Na-Nakorn U, Sukmanomon S, Taniguchi N, et al. (2007). Mitochondrial DNA diversity of the Asian moon scallop, Amusium pleuronectes (Pectinidae), in Thailand. Mar. Biotechnol. 9: 352-359.

Mantel N (1967). The detection of disease clustering and a generalized regression approach. Cancer Res. 27: 209-220.

Miller MP (1997). Tools for population genetic analysis (TFPGA). Version 1.3: A Windows program for the analysis of allozyme and molecular population genetic data. Computer software distributed by author.

Nei M (1973). Analysis of Gene Diversity in Subdivided Populations. Proc. Natl. Acad. Sci. U.S.A. 70: 3321-3323.

Nei M (1978). Estimation of average heterozygosity and genetic distance from a small number of individuals. Genetics 89: 583-590. 
Patwary MU, Kenchington EL, Bird CJ and Zouros E (1994). The use of random amplified polymorphic DNA markers in genetic studies of the scallop Placopecten magellanicus (Gmelin, 1791). J. Shellfish Res. 13: 547-553.

Pawiro S (2004). Regional Review on Marine Aquaculture Products Demand, Trades and Market. INFOFISH, China, 25.

Pineda J, Hare JA and Sponaugle S (2007). Larval transport and dispersal in the coastal ocean and consequences for population connectivity. Oceanography 20: 22-39.

Posada D (2004). Collapse 1.2. Online. Available at [http:// Darwin. Uvigo.es]. Accessed January 17, 2006.

Riddle BR and Hafner DJ (2007). Phylogeography in Historical Biogeography: Investigating the Biogeographic Histories of Populations, Species, and Young Biotas. In: Biogeography in a Changing World (Ebach MC and Tangney R, eds.). CRC Press, Boca Raton, 161-176.

Shazili NAM, Yunus K, Ahmad AS, Abdullah N, et al. (2006). Heavy metal pollution status in the Malaysian aquatic environment. Aquat. Ecosyst. Health Manag. 9: 137-145.

Soroka M (2008). Doubly uniparental inheritance of mitochondrial DNA in the freshwater bivalve Anodonta woodiana (Bivalvia: Unionidae). Folia Biol. 56: 91-95.

Star B, Apte S and Gardner JPA (2003). Genetic structuring among populations of the greenshell mussel Perna canaliculus revealed by analysis of randomly amplified polymorphic DNA. Mar. Ecol. Progr. Series 249: 171-182.

Tajima F (1989). Statistical method for testing the neutral mutation hypothesis by DNA polymorphism. Genetics 123 : 585-595.

Tang S, Popongviwat A, Klinbunga S, Tassanakajon A, et al. (2005). Genetic heterogeneity of the tropical abalone (Haliotis asinina) revealed by RAPD and microsatellite analyses. J. Biochem. Mol. Biol. 38: 182-190.

Tremblay RL and Ackerman JD (2001). Gene flow and effective population size in Lepanthes (Orchidaceae): a case for genetic drift. Bio. J. Linn. Soc. 72: 47-62.

Trenkel VM, Godo OR, Handegard NO and Patel R (2004). Studying the relationship between spatial fish distributions and trawl catches. ICES1, 1.13.

Walker JM, Bogan AE, Bonfiglio EA, Campbell DC, et al. (2007). Primers for amplifying the hypervariable, maletransmitted COII-COI junction region in amblemine freshwater mussels (Bivalvia: Unionidae: Ambleminae). Mol. Ecol. Notes 7: 489-491.

Yeh FC, Yang R and Boyle T (1999). Popgene version 1.31. Microsoft Windows-based freeware for population genetic analysis. Alberta: University of Alberta and Centre for International Forestry Research, Edmonton. 